\title{
心電図コンピュー夕診断の問題点 沉用自動心電計による解析精度の検討
}

新 博次* 遠藤康実* 八島正明*

加藤貴雄* 岸田 浩* 早川弘一*

最近の汎用自動診断心電計 2 機種による自動診断精度につき検討した.

Positve predictability (PPD)はWPW 症候群で69～88\%，心房細動60～93\%， I 度房室ブロック92〜98\%であった。不整脈の診断精度はP波の認識精度に問題があり， 全般にPPDが低下し，ことに上室性期外収縮では false negativeが多くみられた。

心筋梗塞の診断は, 側壁梗塞の診断精度が他の部位と比し劣る傾向であった，異常Q波 の感度は100\%であったが，PPDは57\%亡低值を示し，R波増高不良は感度55\%，PPD 92\%であり, 心筋梗塞の部位別診断精度に反映しているものと考えられた。

正常範囲内之診断された1,139例のPPDは98\%であり, その false positve には臨 床上問題亡なる所見は含まれず, 正常範囲内と表示された場合の信頼性は高いものと考え られた。

(心電図12：No.2, 153〜 160, 1992)

\section{I .はじめに}

心電図自動診断はコンピュータを利用し， 心電図自動診断プログラムにより心電図の調 律，ならびに波形診断を行うものである.

心電図波形をコンピュータにより解析しよ

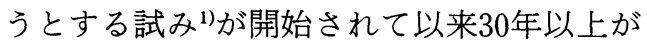
経過し，最近では心電図記録と同時に診断名， 計測値がプリントされる心電計が普及してき た.そして自動診断の信頼性を高めるため,

\begin{tabular}{|c|c|}
\hline Key Words & $\begin{array}{l}\text { ・心電図自動診断 } \\
\text { ・コンピュータ診断 } \\
\text { - positive predictability } \\
\text { ○筋梗塞 }\end{array}$ \\
\hline
\end{tabular}

* 日本医科大学第 1 内科

（テ113 東京都文京区千駄木 1-1-5) 読み逃し(false negative)，読みすぎ(false positive)を少なくし, 各診断の感度 (sensitivity)ならびに特異度 (specificity)を高める努 力がなされ, 最近の自動診断心電計は, 一般 の健康診断には対応し得るものと考えられる.

一方，これら自動診断心電計を使用する立 場では, その診断の信頼性がいかなるもので あるかを知っている必要がある。しかしなが ら現在, 本邦で汎用されている自動心電計の 診断精度につき検討した報告は少ない。そこ で自動診断心電計による解析精度につき検討 し, 今後さらにこれら自動診断システムの信 頼性が高められることを期待し, 本研究を施 行した。 


\section{II. 対象と方法}

\section{1. 調査対象と調査項目}

（1）籐間病院総合健診システムを平成 2 年 度に受診した延べ14,261例の自動診断心電図 (フクダ電子 FCP 270型自動心電計) より「心 筋梗塞」,「WPW 症候群」,「心房細動」,「I 度房室ブロック」の positive predictability (PPD)を求めた。

(2) 平成 3 年 2 月から 6 月までに日本電気 健康管理センターを受診した 2,274 例の自動 診断心電図(日本電気 KARTIZER 5500) で 「正常範囲内」と診断されたものの PPD，そ して「正常範囲内」以外の診断がなされたも ののうち, 任意の 286 例で 3 回連続して心電図 を記録し，延べ858例の自動診断につきその PPD を求め,さらに各診断名が 3 回連続して 診断される確率についても検討した。

（3）日本医科大学第 1 内科のほか, 多施設の 病院で記録された延べ1,072例の自動診断心 電図(日本電気 KARTIZER 5500)より, 各診 断名の PPD, 感度, 物異度, 偽陽性率, 予測 度 (predictive value)を求めた。

\section{2. 自動診断心電図所見の判定と解析精度 の評価}

自動診断の正誤ならびに心電図所見の判定 は，著者のうち 3 名以上で行い，その全員の 合意により決定し，自動診断された所見を以 下の 4 群に分類した。

(1) True positive(TP) : その心電図所見 が正しく自動診断されたもの (正診)
(2) True negatave $(\mathrm{TN})$ : その心電図所 見がないことを正しく自動診断したもの

(3) False positive(FP) : その心電図所見 を誤って自動診断したもの (誤診)

(4) False negative $(\mathrm{FN})$ : その心電図所 見を自動診断で読めなかったもの

なお，自動診断解析精度の指標として用い た, PPD, 感度, 特異度, 偽陽性率, 予測度 は表 1 に示す方法 ${ }^{21}$ てて求めた。

\section{III. 成 績}

1. 平成 2 年度, 籐間病院総合健診システ 厶を受診した 14,261 例のうち自動診断で「心 筋梗塞」と診断されたものは85例，「心筋梗塞 疑い」が240例，「心筋梗塞否定できず」490例 であった。また「WPW 症候群」が16例，「心 房細動」45例，「I 度房室ブロック」155例で あった。PPDを求められたのは「心筋梗 塞」,「WPW 症候群」, 「心房細動」,「 I 度房 室ブロック」で，それぞれ $15 / 85(18.8 \%) ， 14 /$ $16(87.5 \%), 27 / 45(60.0 \%), 142 / 155(91.6 \%)$ であった。

2.日本電気健康管理センターを受診した 2,274 例で「正常範囲内」と診断されたものは 1,139 例であり，そのPPDは $1,119 /$ 1,139(98.2\%)であった。「正常範囲内」の false positive 20 例の内訳は「左側偏位」が10 例 $50 \%$, 「不完全右脚ブロック」 7 例 $35 \%$, 「 I 度房室ブロック」 2 例 $10 \%$ ，「右房負荷」 1 例 5 \%であった。 また, 286例, 858回の心電図 に表示された延べの診断件数は1,337件であ

表 1 PPD, 感度, 特異度, 偽陽性率, 予測度の求め方

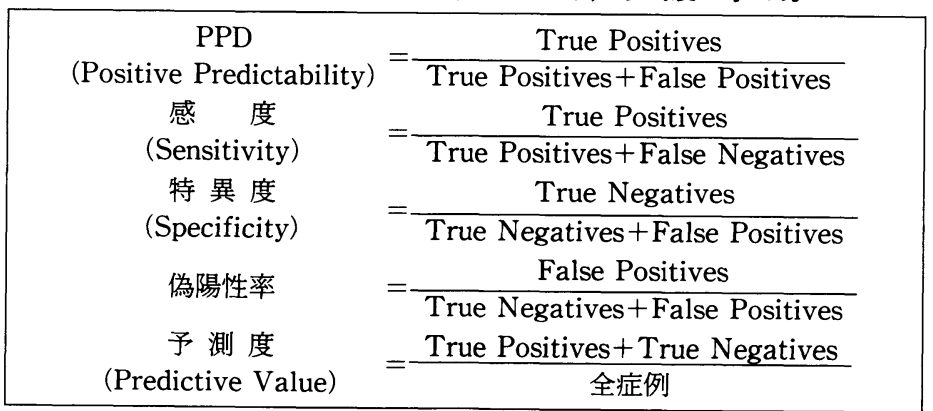


り, 各診断名の PPD ならびに 3 回連続して 診断される確率を表 2 に示す.

PPD が100\%を示したのは「洞性頻脈」,「洞 性徐脈」,「異所性心房調律」,「時計方向回 転」,「完全右脚ブロック」, 「高電位」,「左房 負荷」，「右房負荷」，「T波増高」であった。 これに対し PPD が低值 (50\%未満)を示した のは「接合部性調律」,「右軸偏位」,「極端な 軸偏位」「PR 短縮」,「II 度房室ブロック」, 「完全房室ブロック」,「完全左脚ブロック」, $「$ 心室内伝導障害」,「低電位差」,「右室肥大 疑い」,「著明な ST 降下」,「下壁梗塞」,「側壁 梗塞」,「下壁梗塞疑い」,「側壁梗塞疑い」,「純

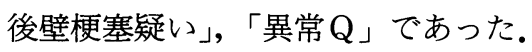

次に, 同一の診断名が 3 回連続して表示さ れる確率が低值 (50\%未満)を示したものは, 本来環境因子により影響されやすい心拍変動 に関連した診断名，また期外収縮のごとき安 定して出現するとはかぎらないもを除外して みると,「心房細動」,「右軸偏位」「極端な軸 偏位」,「左軸偏位」,「PR 短縮」,「II度房室ブ ロック」,「完全房室ブロック」,「WPW 症候 群」「完全左脚ブロック」, 「心室内伝導障 害」, 「左室肥大」, 「左室肥大疑い」, 「右房負 荷」，「著明な ST 降下」，「ST 降下」，「ST 降 下と陰性 $\mathrm{T}\lrcorner$, 「陰性 $\mathrm{T}\lrcorner$, 「下壁梗塞」,「側壁 梗塞」,「下壁梗塞疑い」,「側壁梗塞疑い」,「異 常 Q」であった。これに対し，再現性が高く， 3 回連続して診断される確率が比較的高值 (80\%以上)を示したのは「洞性頻脈」，「完全 右脚ブロック」,「右室肥大疑い」, 「左房負 荷」「純後壁梗塞疑い」であった。

診断名でみると，心筋梗塞では「前壁中隔 梗塞の疑い」が PPD (67.4\%)，3 回連続の確 率 $(70.6 \%)$ ともに他の梗塞部位の診断と比し 高值を示した。 心筋梗塞の診断に関係すると 考えられる「異常 $\mathrm{Q} 」$,「R増高不良」につき みると, 後者でより高い PPD が得られ，3 回 連続の確率も優っていた。
表 2 KARTIZER 5500によるPPD と 3 回連統して 診断される確率 (日本電気健康管理センター)

\begin{tabular}{|c|c|c|}
\hline 診断名 & $\begin{array}{l}\text { PPD } \\
(\%)\end{array}$ & $\begin{array}{c}3 \text { 回連続の確率 } \\
(\%)\end{array}$ \\
\hline 心室性期外収縮 & $18 / 26(69.2)$ & $5 / 14(35.7)$ \\
\hline 上室性期外収縮 & $28 / 30(93.3)$ & $6 / 15(40)$ \\
\hline 洞性頻脈 & $27 / 27(100)$ & $8 / 10(80)$ \\
\hline 洞性徐脈 & $44 / 44(100)$ & $6 / 20(30)$ \\
\hline 洞性不整徐脈 & $7 / 8(87.5)$ & $0 / 7(0)$ \\
\hline 洞性不整脈 & $29 / 36(80.6)$ & $2 / 26(7.7)$ \\
\hline 心房細動 & $5 / 6(83.3)$ & $1 / 3(33.3)$ \\
\hline 異所性心房調律 & $11 / 11(100)$ & $3 / 4(75)$ \\
\hline 接合部性調律 & $0 / 4(0)$ & $1 / 2(50)$ \\
\hline 反時計方向回転 & $160 / 173(92.5)$ & $45 / 70(64.3)$ \\
\hline 時計方向回転 & $13 / 13(100)$ & $3 / 6(50)$ \\
\hline 右軸偏位 & $0 / 4(0)$ & $0 / 2(0)$ \\
\hline 軽度の右軸偏位 & $47 / 52(90.4)$ & $14 / 22(63.6)$ \\
\hline 左軸偏位 & $18 / 19(94.7)$ & $4 / 10(40)$ \\
\hline 極端な軸偏位 & $0 / 2(0)$ & $0 / 1(0)$ \\
\hline PR 短縮 & $6 / 97(6.2)$ & $19 / 43(44.2)$ \\
\hline I 度 $\mathrm{AVB}$ & $49 / 51(96.1)$ & $15 / 19(52.6)$ \\
\hline II 度 $\mathrm{AVB}$ & $0 / 5(0)$ & $0 / 3(0)$ \\
\hline CAVB & $0 / 5(0)$ & $1 / 3(33.3)$ \\
\hline WPW 症候群 & $11 / 16(68.8)$ & $3 / 8(37.5)$ \\
\hline ICRBBB & $75 / 89(84.3)$ & $25 / 35(71.4)$ \\
\hline CRBBB & $28 / 28(100)$ & $9 / 10(90)$ \\
\hline CLBBB & $0 / 4(0)$ & $0 / 3(0)$ \\
\hline 心室内伝導障害 & $4 / 9(44.4)$ & $2 / 5(40)$ \\
\hline 低電位差 & $41 / 86(47.7)$ & $23 / 35(65.7)$ \\
\hline 左室肥大 & $9 / 13(69.2)$ & $2 / 7(28.6)$ \\
\hline 左室肥大疑い & $15 / 19(78.9)$ & $3 / 10(30)$ \\
\hline 高電位 & $24 / 24(100)$ & $6 / 10(60)$ \\
\hline 右室肥大疑い & $0 / 6(0)$ & $2 / 2(100)$ \\
\hline 左房負荷 & $3 / 3(100)$ & $1 / 1(100)$ \\
\hline 右房負荷 & $7 / 7(100)$ & $1 / 4(25)$ \\
\hline 著明な ST 降下 & $0 / 5(0)$ & $0 / 4(0)$ \\
\hline ST 降下 & $15 / 26(57.7)$ & $3 / 16(18.8)$ \\
\hline ST 上昇 & $30 / 44(68.2)$ & $10 / 20(50)$ \\
\hline ST 降下と陰性 $\mathrm{T}$ & $16 / 24(66.7)$ & $4 / 13(30.8)$ \\
\hline $\mathrm{ST}$ 上昇と陰性 $\mathrm{T}$ & $14 / 17(82.4)$ & $4 / 5(80)$ \\
\hline 陰性 T & $49 / 52(94.2)$ & $15 / 22(45.5)$ \\
\hline 平低 T & $19 / 24(79.2)$ & $7 / 10(70)$ \\
\hline T波増高 & $18 / 18(100)$ & $5 / 7(71.4)$ \\
\hline \multicolumn{3}{|l|}{ 心筋梗塞 } \\
\hline 下壁 & $0 / 4(0)$ & $0 / 4(0)$ \\
\hline 側壁 & $0 / 12(0)$ & $0 / 7(0)$ \\
\hline \multicolumn{3}{|l|}{ 心筋梗塞疑い } \\
\hline 前壁中隔 & $29 / 43(67.4)$ & $12 / 17(70.6)$ \\
\hline 下壁 & $2 / 49(4.1)$ & $8 / 23(34.8)$ \\
\hline 側壁 & $1 / 4(25)$ & $0 / 4(0)$ \\
\hline 純後壁 & $0 / 6(0)$ & $5 / 6(83.3)$ \\
\hline 異常 Q & $7 / 49(14.3)$ & $7 / 27(25.9)$ \\
\hline $\mathrm{R}$ 増高不良 & $23 / 27(85.2)$ & $6 / 11(54.5)$ \\
\hline
\end{tabular}

$\mathrm{AVB}$ : 房室ブロック, CAVB : 完全房室ブロック ICRBBB : 不完全右脚ブロック, CRBBB : 完全右脚 ブロック, CLBBB : 完全左脚ブロック 
表 3-1 各診断名別の診断精度(KARTIZER 5500：多施設病院1，072例）

\begin{tabular}{|c|c|c|c|c|c|c|c|c|c|}
\hline 診断名 & FN & $\mathrm{FP}$ & $\mathrm{TN}$ & $\mathrm{TP}$ & 感度 & PPD & 特異度 & 偽陽性率 & 予測度 \\
\hline 急性前壁中隔梗塞 & 0 & 0 & 1,071 & 1 & 1.000 & 1.000 & 1.000 & 0.000 & 1.000 \\
\hline 陳旧性前壁中隔梗塞 & 2 & 1 & 1,069 & 0 & 0.000 & 0.000 & 0.999 & 0.001 & 0.997 \\
\hline 急性前壁中隔梗塞の疑い & 0 & 1 & 1,065 & 6 & 1.000 & 0.857 & 0.999 & 0.001 & 0.999 \\
\hline 陳旧性前壁中隔梗塞の疑い & 2 & 0 & 1,065 & 5 & 0.714 & 1.000 & 1.000 & 0.000 & 0.998 \\
\hline 急性前壁梗塞 & 0 & 0 & 1,071 & 1 & 1.000 & 1.000 & 1.000 & 0.000 & 1.000 \\
\hline 陳旧性前壁梗塞 & 0 & 0 & 1,063 & 9 & 1.000 & 1.000 & 1.000 & 0.000 & 1.000 \\
\hline 急性前壁梗塞の疑い & 0 & 0 & 1,071 & 1 & 1.000 & 1.000 & 1.000 & 0.000 & 1.000 \\
\hline 陳旧性前壁梗塞の疑い & 2 & 0 & 1,069 & 1 & 0.333 & 1.000 & 1.000 & 0.000 & 0.998 \\
\hline 急性側壁梗塞 & 0 & 1 & 1,071 & 0 & $\longrightarrow$ & 0.000 & 0.999 & 0.001 & 0.999 \\
\hline 陳旧性側壁梗塞 & 1 & 6 & 1,058 & 7 & 0,875 & 0.538 & 0.994 & 0.006 & 0.993 \\
\hline 急性側壁梗塞の疑い & 1 & 0 & 1,071 & 0 & 0.000 & $\longrightarrow$ & 0.999 & 0.001 & 0.999 \\
\hline 陳旧性側壁梗塞の疑い & 0 & 2 & 1,067 & 3 & 1.000 & 0.600 & 0.998 & 0.002 & 0.998 \\
\hline 急性高位側壁梗塞 & 0 & 0 & 1,072 & 0 & - & - & 1.000 & 0.000 & 1.000 \\
\hline 陳旧性高位側壁梗塞 & 0 & 1 & 1,070 & 1 & 1.000 & 0.500 & 0.999 & 0.001 & 0.999 \\
\hline 急性高位側壁梗塞の疑い & 0 & 0 & 1,072 & 0 & 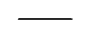 & 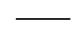 & 1.000 & 0.000 & 1.000 \\
\hline 陳旧性高位側壁梗塞の疑い & 0 & 2 & 1,067 & 3 & 1.000 & 0.600 & 0.998 & 0.002 & 0.998 \\
\hline 急性下壁梗塞 & 0 & 0 & 1,068 & 4 & 1.000 & 1.000 & 1.000 & 0.000 & 1.000 \\
\hline 陳旧性下壁梗塞 & 4 & 0 & 1,055 & 13 & 0.765 & 1.000 & 1.000 & 0.000 & 0.996 \\
\hline 急性下壁梗塞の疑い & 0 & 0 & 1,072 & 0 & & $\longrightarrow$ & 1.000 & 0.000 & 1.000 \\
\hline 陳旧性下壁梗塞の疑い & 2 & 6 & 1,031 & 33 & 0.943 & 0.846 & 0.995 & 0.005 & 0.993 \\
\hline 急性前壁側壁梗塞 & 0 & 0 & 1,072 & 0 & - & - & 1.000 & 0.000 & 1.000 \\
\hline 陳旧性前壁側壁梗塞 & 0 & 0 & 1,069 & 3 & 1.000 & 1.000 & 1.000 & 0.000 & 1.000 \\
\hline 急性前壁側壁梗塞の疑い & 0 & 0 & 1,072 & 0 & - & & 1.000 & 0.000 & 1.000 \\
\hline 陳旧性前壁側壁梗塞の疑い & 0 & 0 & 1,072 & 0 & - & $\overline{ }$ & 1.000 & 0.000 & 1.000 \\
\hline 急性下壁側壁梗塞 & 0 & 0 & 1,072 & 0 & - & - & 1.000 & 0.000 & 1.000 \\
\hline 陳旧性下壁側壁梗塞 & 0 & 1 & 1,066 & 5 & 1.000 & 0.833 & 0.999 & 0.001 & 0.999 \\
\hline 急性下壁側壁梗塞の疑い & 0 & 0 & 1,072 & 0 & & & 1.000 & 0.000 & 1.000 \\
\hline 陳旧性下壁側壁梗塞の疑い & 0 & 0 & 1,072 & 0 & & & 1.000 & 0.000 & 1.000 \\
\hline 純型後壁梗塞の疑い & 3 & 5 & 1,061 & 3 & 0.500 & 0.375 & 0.995 & 0.005 & 0.993 \\
\hline 異常Q波 & 0 & 21 & 1,023 & 28 & 1.000 & 0.571 & 0.980 & 0.020 & 0.980 \\
\hline R波増高不良 & 9 & 1 & 1,051 & 11 & 0.550 & 0.917 & 0.999 & 0.001 & 0.991 \\
\hline 左軸偏位 & 2 & 4 & 1,033 & 33 & 0.943 & 0.892 & 0.996 & 0.004 & 0.994 \\
\hline 右軸偏位 & 0 & 1 & 1,067 & 4 & 1.000 & 0.800 & 0.999 & 0.001 & 0.999 \\
\hline 軽度の右軸偏位 & 0 & 6 & 1,032 & 34 & 1.000 & 0.850 & 0.994 & 0.006 & 0.994 \\
\hline 極端な軸偏位 & 0 & 2 & 1,066 & 4 & 1.000 & 0.667 & 0.998 & 0.002 & 0.998 \\
\hline 軸測定不能 & 0 & 2 & 1,070 & 0 & - & 0.000 & 0.998 & 0.002 & 0.998 \\
\hline 左室肥大 & 2 & 1 & 1,035 & 34 & 0.944 & 0.971 & 0.999 & 0.001 & 0.997 \\
\hline 左室肥大の疑い & 0 & 5 & 1,054 & 13 & 1.000 & 0.722 & 0.995 & 0.005 & 0.995 \\
\hline 高電位 & 2 & 14 & 930 & 126 & 0.984 & 0.900 & 0.985 & 0.015 & 0.985 \\
\hline 右室肥大 & 0 & 1 & 1,071 & 0 & & 0.000 & 0.999 & 0.001 & 0.999 \\
\hline 右室肥大の疑い & 0 & 5 & 1,066 & 1 & 1.000 & 0.167 & 0.995 & 0.005 & 0.995 \\
\hline 左房負荷 & 1 & 4 & 1,064 & 3 & 0.750 & 0.429 & 0.996 & 0.004 & 0.995 \\
\hline 右房負荷 & 1 & 2 & 1,066 & 3 & 0.750 & 0.600 & 0.998 & 0.002 & 0.995 \\
\hline 両房負荷 & 0 & 0 & 1,072 & 0 & & & 1.000 & 0.000 & 1.000 \\
\hline 著明な ST 降下 & 0 & 8 & 1,054 & 10 & 1.000 & 0.556 & 0.992 & 0.008 & 0.993 \\
\hline 著明な ST 降下 (接合部降下) & 0 & 10 & 1,056 & 6 & 1.000 & 0.375 & 0.991 & 0.009 & 0.991 \\
\hline ST 降下 & 15 & 28 & 919 & 110 & 0.880 & 0.797 & 0.970 & 0.030 & 0.960 \\
\hline 著明な ST 上昇 & 0 & 0 & 1,072 & 0 & & 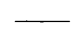 & 1.000 & 0.000 & 1.000 \\
\hline ST 上昇 & 0 & 11 & 1,046 & 15 & 1.000 & 0.577 & 0.990 & 0.010 & 0.990 \\
\hline 著明な ST 降下を伴う陰性T波 & 0 & 3 & 1,056 & 13 & 1.000 & 0.813 & 0.997 & 0.003 & 0.997 \\
\hline ST 降下を伴う陰性T波 & 0 & 14 & 1,013 & 45 & 1.000 & 0.763 & 0.986 & 0.014 & 0.987 \\
\hline 著明な ST 上昇を伴う陰性 $\mathrm{T}$ 波 & 0 & 0 & 1,072 & 0 & - & $\longrightarrow$ & 1.000 & 0.000 & 1.000 \\
\hline $\mathrm{ST}$ 上昇を伴う陰性 $\mathrm{T}$ 波 & 0 & 0 & 1,070 & 2 & 1.000 & 1.000 & 1.000 & 0.000 & 1.000 \\
\hline 陰性T波 & 2 & 12 & 968 & 90 & 0.978 & 0.882 & 0.988 & 0.012 & 0.987 \\
\hline 平低T波 & 5 & 23 & 962 & 82 & 0.943 & 0.781 & 0.977 & 0.023 & 0.974 \\
\hline T波増高 & 1 & 0 & 1,069 & 2 & 0.667 & 1.000 & 1.000 & 0.000 & 0.999 \\
\hline
\end{tabular}


表 3- 2

\begin{tabular}{|c|c|c|c|c|c|c|c|c|c|}
\hline 診断名 & FN & FP & $\mathrm{TN}$ & $\mathrm{TP}$ & 感度 & PPD & 特異度 & 偽陽性率 & 予測度 \\
\hline 完全房室ブロック & 0 & 1 & 1,069 & 2 & 1.000 & 0.667 & 0.999 & 0.001 & 0.999 \\
\hline 第 2 度房室ブロック (ウエンケバッ八型) & 0 & 0 & 1,072 & 0 & & & 1.000 & 0.000 & 1.000 \\
\hline 第 2 度房室ブロック (モビッッ II 型) & 0 & 0 & $\mid 1,072$ & 0 & & & 1.000 & 0.000 & 1.000 \\
\hline 第 1 度房室ブロック & 6 & 1 & 1,016 & 49 & 0.891 & 0.980 & 0.999 & 0.001 & 0.993 \\
\hline WPW 症候群 & 6 & 1 & 1,059 & 6 & 0.500 & 0.857 & 0.999 & 0.001 & 0.993 \\
\hline PR 短縮 & 0 & 10 & 1,048 & 14 & 1.000 & 0.583 & 0.991 & 0.009 & 0.991 \\
\hline 完全左脚ブロック & 0 & 1 & 1,065 & 6 & 1.000 & 0.857 & 0.999 & 0.001 & 0.999 \\
\hline 不完全左脚ブロック & 0 & 1 & 1,071 & 0 & & 0.000 & 0.999 & 0.001 & 0.999 \\
\hline 完全右脚ブロック & 2 & 1 & 1,027 & 42 & 0.955 & 0.977 & 0.999 & 0.001 & 0.997 \\
\hline 不完全右脚ブロック & 8 & 5 & 1,029 & 30 & 0.789 & 0.857 & 0.995 & 0.005 & 0.998 \\
\hline 心室内伝導障害 & 2 & 4 & 1,064 & 2 & 0.500 & 0.333 & 0.996 & 0.004 & 0.994 \\
\hline 左脚前枝ブロック & 0 & 2 & 1,068 & 2 & 1.000 & 0.500 & 0.998 & 0.002 & 0.998 \\
\hline 左脚後枝ブロック & 0 & 0 & 1,072 & 0 & - & - & 1.000 & 0.000 & 1.000 \\
\hline 心室性期外収縮 & 1 & 6 & 1,051 & 14 & 0.933 & 0.700 & 0.994 & 0.006 & 0.993 \\
\hline 心室性期外収縮 (多形性) & 0 & 3 & 1,062 & $\begin{array}{r}17 \\
7\end{array}$ & 1.000 & 0.700 & 0.997 & 0.003 & 0.997 \\
\hline 心室性期外収縮 (移動連結性) & 0 & 0 & 1,072 & 0 & & & 1.000 & 0.000 & 1.000 \\
\hline 心室性期外収縮 ( $\mathrm{R}$ on $\mathrm{T}$ ) & 0 & 0 & 1,071 & 1 & 1.000 & 1.000 & 1.000 & 0.000 & 1.000 \\
\hline 心室性期外収縮 ( 2 連発) & 0 & 1 & 1,070 & 1 & 1.000 & 0.500 & 0.999 & 0.001 & 0.999 \\
\hline 心室性期外収縮 ( 2 段脈) & 0 & & 1,052 & 19 & 1.000 & 0.950 & 0.999 & 0.001 & 0.999 \\
\hline 心室性期外収縮 (頻発) & 0 & & 1,057 & 12 & 1.000 & 0.800 & 0.997 & 0.003 & 0.997 \\
\hline 上室性期外収縮 & 11 & 1 & 1,042 & 18 & 0.621 & 0.947 & 0.999 & 0.001 & 0.989 \\
\hline 上室性期外収縮(頻発) & 0 & 0 & 1,065 & 7 & 1.000 & 1.000 & 1.000 & 0.000 & 1.000 \\
\hline 上室性期外収縮 (連発) & 0 & 0. & 1,072 & 0 & & & 1.000 & 0.000 & 1.000 \\
\hline 心室頻拍(持続性) & 1 & 0 & 1,070 & 1 & 0.500 & 1.000 & 1.000 & 0.000 & 0.999 \\
\hline 心室頻拍 (非持続性) & 0 & 0 & 1,072 & 0 & & 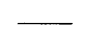 & 1.000 & 0.000 & 1.000 \\
\hline 心室固有調律 & 0 & 0. & 1,072 & 0 & - & - & 1.000 & 0.000 & 1.000 \\
\hline 心房細動 & 5 & 1 & 1,029 & 37 & 0.881 & 0.974 & 0.999 & 0.001 & 0.994 \\
\hline 心房細動 (頻脈) & 0 & 0 & $1,065 \mid$ & 7 & 1.000 & 1.000 & 1.000 & 0.000 & 1.000 \\
\hline 心房細動 (徐脈) & 0 & 0 & 1,071 & 1 & 1.000 & 1.000 & 1.000 & 0.000 & 1.000 \\
\hline 心房粗動 & 0 & 0. & 1,072 & 0 & & & 1.000 & 0.000 & 1.000 \\
\hline 上室性頻拍 & 0 & 0 & 1,072 & 0 & - & $\overline{-}$ & 1.000 & 0.000 & 1.000 \\
\hline 異所性心房調律 & 0 & 0 & 1,072 & 0 & - & & 1.000 & 0.000 & 1.000 \\
\hline 異所性心房頻拍 & 0 & 1 & 1,071 & 0 & - & 0.000 & 0.999 & 0.001 & 0.999 \\
\hline 接合部調律 & 1 & 2 & 1,069 & 0 & 0.000 & 0.000 & 0.998 & 0.002 & 0.997 \\
\hline 接合部頻拍 & 0 & 0 & 1,072 & 0 & $\longrightarrow$ & - & 1.000 & 0.000 & 1.000 \\
\hline 洞房ブロック & 0 & 0 & 1,072 & 0 & - & - & 1.000 & 0.000 & 1.000 \\
\hline 洞性頻脈 & 1 & 3 & 1,027 & 41 & 0.976 & 0.932 & 0.997 & 0.003 & 0.996 \\
\hline 洞性徐脈 & 1 & 1 . & 1,053 & 17 & 0.944 & 0.944 & 0.999 & 0.001 & 0.998 \\
\hline 洞性不整徐脈 & 0 & 0 & 1,070 & 2 & 1.000 & 1.000 & 1.000 & 0.000 & 1.000 \\
\hline 洞性不整脈 & 3 & 10 & $\mid 1,025$ & 34 & 0.919 & 0.773 & 0.990 & 0.001 & 0.988 \\
\hline 確定できない調律 & 0 & 2 & 1,063 & 7 & 1.000 & 0.778 & 0.998 & 0.002 & 0.998 \\
\hline 確定できない頻脈 & 1 & 0 & 1,070 & 1 & 0.500 & 1.000 & 1.000 & 0.000 & 0.999 \\
\hline 確定できない徐脈 & 0 & 0 & 1,071 & 1 & 1.000 & 1.000 & 1.000 & 0.000 & 1.000 \\
\hline 確定できない心室調律 & 0 & 0 & 1,071 & 1 & 1.000 & 1.000 & 1.000 & 0.000 & 1.000 \\
\hline 低電位差 (四肢誘導) & 1 & 2 & 1,061 & 8 & 0.889 & 0.800 & 0.998 & 0.002 & 0.997 \\
\hline 低電位差 (胸部誘導) & 0 & & 1,067 & 4 & 1.000 & 0.800 & 0.998 & 0.002 & 0.999 \\
\hline 低電位差 & 5 & 0. & 1,067 & 0 & 0.000 & & 1.000 & 0.000 & 0.995 \\
\hline QT 延長 & 3 & 6 & 1,060 & 3 & 0.500 & 0.333 & 0.994 & 0.006 & 0.992 \\
\hline 右胸心 & 1 & 0 & 1,071 & 0 & 0.000 & & 1.000 & 1.000 & 0.999 \\
\hline 四肢電極付け違い & 1 & 0 & 1,071 & 0 & 0.000 & $\ldots$ & 1.000 & 1.000 & 0.999 \\
\hline 人工ペースメーカ心電図 & 1 & 7. & 1,057 & 7 & 0.875 & 0.500 & 0.993 & 0.007 & 0.993 \\
\hline 正常範囲内 & 54 & 20 & 668 & 330 & 0.859 & 0.943 & 0.971 & 0.029 & 0.931 \\
\hline
\end{tabular}


心筋梗塞の部位別

表 4 心筋梗塞の部位別，ならびに「断定診断」「疑い」別の竝断精度

\begin{tabular}{|l|r|r|c|r|c|c|c|c|c|}
\hline \multicolumn{1}{|c|}{ 梗塞部位 } & FN & FP & TN & TP & 感度 & PPD & 特異度 & 為陽性率 & 予測度 \\
\hline 前壁中隔 & 4 & 2 & 1,054 & 12 & 0.750 & 0.857 & 0.998 & 0.002 & 0.994 \\
\hline 前壁 & 2 & 0 & 1,058 & 12 & 0.857 & 1.000 & 1.000 & 0.000 & 0.998 \\
\hline 側壁 & 2 & 9 & 1,051 & 10 & 0.833 & 0.526 & 0.992 & 0.008 & 0.990 \\
\hline 高位側壁 & 0 & 3 & 1,065 & 4 & 1.000 & 0.571 & 0.997 & 0.003 & 0.997 \\
\hline 下壁 & 6 & 6 & 1,010 & 50 & 0.893 & 0.893 & 0.994 & 0.006 & 0.989 \\
\hline 前壁側壁 & 0 & 0 & 1,069 & 3 & 1.000 & 1.000 & 1.000 & 0.000 & 1.000 \\
\hline 下壁側壁 & 0 & 1 & 1,066 & 5 & 1.000 & 0.833 & 0.999 & 0.001 & 0.999 \\
\hline
\end{tabular}

心筋梗塞, 心筋梗塞の疑い別

\begin{tabular}{|l|r|r|r|r|r|r|r|r|r|}
\hline 心筋梗塞 & 7 & 10 & 1,011 & 44 & 0.863 & 0.815 & 0.990 & 0.010 & 0.984 \\
\hline 心筋梗塞の疑い & 7 & 11 & 1,002 & 52 & 0.881 & 0.825 & 0.989 & 0.011 & 0.983 \\
\hline
\end{tabular}

\section{3. 多施設にて記録された 1,072 例の 自動診断}

表示された診断名別の false positive, false negative, true positive, true negative の実数，ならびに感度，PPD，特異度，偽陽 性率，予測度を表 3 亿示す。

心電図で梗塞部位に関わらず「心筋梗塞」, 「心筋梗塞の疑い」と自動診断されたものは それぞれ54例，63例であった．KARTIZER 5500の自動診断プログラムは，心筋梗塞の診 断を「急性」と「陳旧性」，そしてさらに「断 定診断」と「疑い」の 4 段階に診断するシス テムとなっている．診断の正誤は各レベルで 行ったが, 細分すると各診断名ごとの例数が 少ないため, 心筋梗塞の部位別で分類し，ま た「断定診断」と「疑い」に二分し検討した (表 4 ).

心筋梗塞の部位別の PPD は「前壁中隔」が $85.7 \%$ ，「前壁」 $100 \%$ ，「下壁」 $89.3 \%$ ，「前 側壁」 $100 \%$ と高く，これに対し「側壁」と「高 位側壁」はいずれも50\%台で低い值であった。 感度は「前壁中隔」の75\%が最も低值であり， 特異度はいずれの部位でも $99 \%$ 以上と良好で あった。また偽陽性率はいずれも $1 \%$ 末満， 予測度はいずれも $90 \%$ 以上であった。

他の所見については表 3 に示すごとくであ るが, 感度が75\%未満であったのは, 「R波増 高不良」,「T波増高」,「WPW 症候群」, 「心
室内伝導障害」「「上室性期外収縮」「「心室頻 拍(持続性)」,「QT 延長」などであった。特異 度についてはすべて $97 \%$ 以上であり，偽陽性 率は「右胸心」「四肢電極付け違い」を除き すべて $3 \%$ 以下であった，予測度も「正常範 囲内」が $93 \%$ で最低であり，ほとんどが $99 \%$ 以上となっていた。

\section{IV. 考 案}

\section{1 . 自動診断心電計による診断精度}

本研究では，現在使用されている 2 機種の 自動診断心電計の成績を示したが, 総合健診 システム(FCP 270型)では, 主要診断名の PPD のみしか調査ができなかった.しかしな がら主要診断名の PPDでみるかぎり「筋 梗塞」「心房細動」で低值を示したが, 他の 診断項目は KARTIZER 5500によるものと ほほ同等の診断精度であると考えられ，いず れにおいても「I 度房室ブロック」が $90 \%$ 以 上,「WPW 症候群」が $85 \%$ 以上であった。本 来, 診断精度を比較するには, 同様な母集団 にて比較がなされるべき ${ }^{3)}$ であり, 本研究で も同じKARTIZER 5500を使用しても，母集 団が異なると成績が異なることが示されてい る.

各診断名別で自動診断の精度を PPD でみ ると，1,139例で検討した「正常範囲内」の PPD は98.2\%と高く, false positiveのなか 
には, 臨床的に問題とされるような所見が含 まれていなかった。このことは，この自動診 断プログラムで「正常範囲内」と表示された ときの信頼性は高いものと考えられた。

一方，P波の認識が重要な診断要素となる 「接合部性調律」,「PR 短縮」をはじめ「II度 以上の房室ブロック」,「筋梗塞」などの診 断では false positiveが多くPPD は低值を 示した.ことに「PR 短縮」の PPD が低值で あり，PR 延長を意味する「I 度房室ブロッ ク」の PPD が高值を示したことは，P波の立 ち上がりの認識が不十分であることを示唆す るものであろう。

以前より，心電図自動診断では波形診断よ り不整脈診断にその誤診例が多くみられる4) といわれており，その理由として P波は低電 位であり，識別が困難であることがあげられ ている ${ }^{5), 6)}$. 宮原ら ${ }^{6)}$ は最近の自動診断心電計 数機種を用い不整脈の診断性能を検討し, $\mathrm{P}$ 波の所在は正しく検出されているものの, 最 終診断では有効に生かされていない場合があ ることを指摘し, 診断精度を高めるためには, $\mathrm{P}$ 波をより一層重要視する必要があると述べ ている. 本研究の成績でも II 度以上の房室ブ ロック，上室性期外収縮の診断精度の低下が 示されており，P波の認識は今後さらに検討 すべき課題となろう.これに対し診断が QRS 波の認識に基づく「洞性頻脈」,「洞性徐脈」 などの PPD は高值であった。

多施設病院で記録された自動診断心電図よ り求めた感度でみると $\mathrm{R}$ 波, $\mathrm{T}$ 波の波高, QRS の持続時間に関連した診断所見, 上室性 期外収縮などに対する感度の低下が認められ ている。一方, 特異度はすべての診断項目で 96\%以上，予測度もほとんど $99 \%$ 以上と良好 であった。これは，母集団における有病者数 が少なかったため,いずれの指標も true negative が多数を占めたことに起因するものと考 えられた。

心筋梗塞の診断についてみると「前壁梗塞」 が他の部位の梗塞と比し高いPPD であった。
この診断精度に関係する所見として R増高不 良で高い PPD, 異常 $\mathrm{Q}$ 波で低い PPD が示さ れたことがあげられる，すなわち， R 波の認 識は比較的良好であるが，Q波については読 みすぎる傾向があることを示すものと思われ た.心筋梗塞の部位別ならびに「断定診断」 と「疑い」とに大別してみた感度，特異度は 良好なものであったが，今後有病者のみの母 集団にて検討する必要があろう。

\section{2 . 心電図自動診断の再現性}

自動診断の再現性については本研究と同様 な方法で検討した報告はないが，宮原ら ${ }^{6}$ の 報告に示されたごとく，再現性が高いものは 正解率も高いと考えられる. 入力シグナルが 安定していると仮定すると, 診断基準のボー ダーラインにある所見が心拍ごとに変動する 場合，期外収縮のごとく規則正しく出現する とはかぎらないものでは，その再現性が低く なると考えられる。そこで問題となるのは, 「右室肥大疑い」,「純後壁梗塞疑い」のごと く再現性は高いが低いPPD を示すときであ り，この場合は，診断プログラムないし心電 図波形の認識に問題があると考えられる。

\section{3 . 心電図自動診断の問題点}

本研究の成績で示されたごとく，自動診断 により示される所見の一部は，ほぼ満足する ものとなってはいるが, 臨床的に重要な心筋 梗塞などの診断精度について，現状では不十 分といわざるをえない. 最近では自動診断心 電計が普及し，その診断名がそのまま使用さ れることも想定されるが，医師による見直し の必要があることが確認されたといえよう。

心電図自動診断の信頼性を高めるには PPD, 感度, 特異度, 予測度といった指標を 高めることが望まれる。一方，心疾患の重篤 性を考慮すれば false negative をおそれるた め, 特異度が下がることを承知で感度を高め る努力をすべきとの考えが生まれることにな る3). しかし, 感度は高いが特異度が低いシス テムは, 多くの false positve 例について精密 検査を施行しなければならなくなり，自動診 
断を行う価值が半減するといった矛盾が生ず ることになる。

現在使用されている自動診断心電計の診断 精度は, 本研究で示されたごとく不十分な点 があり，自動診断のみで診療を行うことは問 題が多く，医師による見直しが必要である。 しかしながら「正常範囲内」と診断された場 合には，臨床上問題となる異常所見の見落と しがないレベルまでに，その信頼性が高めら れたともいえよう。

\section{謝辞}

本研究に際し, 籐間病院総合健診システム 加治清行氏, 石川 豊氏, 日本電気健康管理セ ンター沖 恵子氏, 日本電気株式会社岡本克郎 氏, 清水 滋氏, 金澤正樹氏の方々に多大なご 協力をいただいたことに感謝の意を表します。

\section{[文献]}

1) Pipberger HV, Freis ED, Taback L, Mason HL : Preparation of electrocardiographic data for analysis by digital electronic computer. Circulation $21: 413,1960$

2) Rautaharju PM, Blackburn HW, Warren JW : The concepts of sensitivity, specificity and accuracy in evaluation of electrocardiographic, vectorcardiographic and polarcardiographic criteia. J Electrocardiol 9:275, 1976

3 ) 岡島光治: 心電図システム. 岡島光治, 橋口住 久・編, 心電図システムの信頼性, アイピーシ 一, 東京, 1990,1

4 ) 岡本 登, 岩塚 徹：心電図の自動診断とその限 界. 診断と治療 $76: 1809,1988$

5 ）木村栄一, 赤染悌三, 壬生倉裕, 早川弘一, 大 林完二, 二宮理喜：電子計算機による心電図自 動計測. 医用電子と生体工学 $3: 29,1965$

6 ）宮原英夫, 白鷹増男, 池田憲昭: 心電図自動解 析装置の不整脈性能。心電図 $10: 797,1990$ 